\title{
PENERAPAN METODE PEMBELAJARAN PROBLEM SOLVING UNTUK MENINGKATKAN HASIL BELAJAR SISWA PADA MATERI KONSEP MOL
}

\author{
Hasinah Martini ${ }^{1 *}$ \\ ${ }^{1}$ Guru Kimia di Sekolah Menengah Atas Negeri 2 Mataram \\ *Coressponding Author, Email: laluardiangunaqan@gmail.com
}

Received: 21 Agustus 2019

Accepted: 30 November 2019

Publish: 30 November 2019

doi: 10.29303/cep.v2i2.1322

\begin{abstract}
ABSTRAK
Penelitian ini bertujuan untuk menganalisis peningkatan hasil belajar kimia siswa kelas X IPA 1 SMA Negeri 2 Mataram Tahun Pelajaran 2016-2017 pada materi Konsep Mol dengan penerapan metode pembelajaran problem solving. Metode penelitian yang digunakan adalah Penelitian Tindakan Kelas (PTK) yang secara umum terdiri dari 2 (dua) siklus. Masing-masing siklus terdiri dari 4 (empat) tahapan yaitu perencanaan, tindakan, observasi, dan refleksi. Penelitian ini dilaksanakan di kelas X IPA 1 SMAN 2 Mataram pada tahun pelajaran 2016-2017 yang berjumlah 40siswa, 10 siswa laki-laki dan 30 siswa perempuan. Penelitian ini difokuskan pada materi konsep mol yang mencakup konversi jumlah mol ke dalam jumlah partikel, jumlah massa, jumlah volume, hipotesis Avogadro, rumus empiris, rumus molekul, kadar zat, dan pereaksi pembatas. Teknik pengumpulan data yang digunakan adalah tes, lembar observasi, dan angket siswa. Hasil penelitian pada siklus II menunjukkan terjadinya peningkatan aktivitas dan hasil belajar siswa dibandingkan dengan siklus I. Pada siklus II, rata-rata nilai post tes siswa adalah 79,08 dengan siswa sebanyak 35 orang $(88 \%)$ mencapai nilai $\geq 76$. Hasil angket siswa serta hasil observasi terhadap pembelajaran dengan menggunakan metode problem solving juga menunjukkan tanggapan yang baik dari siswa. Hal ini membuktikan bahwa pembelajaran dengan menggunakan metode problem solving memberikan dampak yang positif bagi siswa dalam proses belajar mengajar.
\end{abstract}

Kata kunci: Problem Solving, konsep mol, hasil belajar

\begin{abstract}
This study aimed at analyzing the increase of chemistry learning outcomes of Year X students at SMA Negeri 2 Mataram in the Academic Year of 2016-2017 on the topic of the Concept of Mol using problem solving learning method. The research method used is Classroom Action Research (CAR) which generally consists of 2 (two) cycles, each of which has 4 (four) stages: planning, action, observation, and reflection. This study was conducted with 40 Year X students of SMAN 2 Mataram in the Academic Year of 2016-2017, 10 male and 30 female students. The study focused on the topic of the Concept of Mol, covering: the conversion of mol amount to particle amount, mass amount, volume amount, Avogadro hypothesis, empirical formula, molecular formula, degree of substance, and limiting reactors. The data were collected through test, observation sheet, and students' questionnaire. The result of Cycle II analysis indicates the increase of activity and the students' learning outcomes compared with the result of Cycle I.In Cycle II, the average post-test score was 79.08, in which 35 (88\%) students obtained the score of $\geq 76$. The students' questionnaire and the learning observation also revealed that the use of problem solving learning method had a good response from the students. This confirms that the use of problem solving learning method has a positive impact on the students during the teaching and learning process.
\end{abstract}

Keywords : Problem-Solving Teaching and Learning Method 


\section{PENDAHULUAN}

Saat ini siswa kelas X IPA 1 berjumlah 40 siswa yang terdiri dari 10 laki-laki dan 30 perempuan, berdasarkan pengamatan selama pembelajaran dan data hasil tes awal pada "Konsep Mol" kemampuan siswa kelas X IPA 1 menunjukkan kemampuan yang rendah. Dari 40 siswa, ditemukan hanya 16 orang $(40,0 \%)$ yang berhasil mencapai KKM 76. Sisanya sejumlah 24 siswa atau sebesar $60,0 \%$ tidak berhasil mencapai KKM yang telah ditetapkan guru, yaitu di bawah KKM 76. Artinya siswa kelas X IPA 1 mengalami masalah / kesulitan dalam memahami "Konsep Mol".

Rendahnya kemampuan siswa pada "Konsep Mol" tersebut ditandai dengan hal-hal berikut :

- Kurang perhatian saat mengikuti pembelajaran;

- Siswa tidak fokus saat pembelajaran berlangsung;

- Siswa tidak aktif, dan sebagian besar hanya diam mendengar penjelasan guru;

- Siswa kurang respon ketika mengerjakan LKS;

- Siswa masih bingung melaksanakan perintah guru;

- Siswa tidak banyak yang mengajukan pertanyaan;

- Siswa tidak berani menjawab pertanyaan;

- Jawaban siswa masih jauh dari konsep yang tepat;

Menyadari belum optimalnya kemampuan siswa pada konsep mol yang ditandai dengan rendahnya kemampuan siswa serta $60,0 \%$ siswa belum berhasil mencapai KKM yang telah ditetapkan, menuntut guru melakukan perbaikan pembelajaran, agar kemampuan siswa terhadap materi konsep mol dapat meningkat.

Selama ini, guru hanya menyajikan pembelajaran tentang konsep mol hanya dengan menggunakan ceramah dan metode penugasan tanpa refleksi sehingga siswa tidak aktif dan tidak mendapat pengalaman belajar yang bermakna sesuai dengan konteks dan pengalamannya sehari-hari. Oleh karena itu, kemampuan dan aktivitas siswa perlu ditingkatkan.

Salah satu upaya guru untuk memperbaiki/meningkatkan hasil belajar dan aktivitas siswa dalam pembelajaran tentang konsep mol adalah dengan menggunakan metode pembelajaran problem solving.

Metode pembelajaran problem solving adalah suatu cara mengajar dengan menghadapkan siswa kepada suatu masalah agar dipecahkan atau diselesaikan. Metode ini menuntut kemampuan untuk melihat sebab akibat, mengobservasi problem, mencari hubungan antara berbagai data yang terkumpul kemudian menarik kesimpulan yang merupakan hasil pemecahan masalah. Menurut Jusuf Djajadisastra (1985 : 98) metode pembelajaran problem solving sebagai metode berfikir yang merupakan suatu cara mengajar yang merangsang seseorang untuk menganalisis dan melakukan sintesis dalam kesatuan struktur atau situasi di mana masalah itu berada atas inisiatif sendiri. Sedangkan menurut Mu'Qodin ( 2002 ) mengatakan bahwa problem solving adalah merupakan suatu keterampilan yang meliputi kemampuan untuk mencari informasi, menganalisa situasi, mengidentikasi masalah dengan tujuan untuk menghasilkan alternatif tindakan, kemudian mempertimbangkan alternatif tersebut sehubungan dengan hasil yang dicapai dan pada akhirnya melaksanakan rencana dengan melakukan suatu tindakan yang tepat.

Metode pembelajaran problem solving dipilih dan digunakan sebagai solusi dalam meningkatkan kemampuan dan aktivitas siswa dalam pembelajaran kimia tentang materi konsep mol karena (a) dapat memberikan kemampuan siswa bagaimana cara memecahkan masalah-masalah secara objektif dan tahu benar apa yang dihadapi; (b) melatih siswa untuk bisa memecahkan soal-soal kimia secara sistematis dan mampu mengaitkan konsep yang satu dengan yang lain; (c) membantu siswa memahami konsep-konsep kimia dan saling keterkaitannya dan juga penerapannya untuk menyelesaikan masalah dalm kehidupan seharihari dan teknologi. Hal ini sebagaimana dinyatakan oleh Sanjaya (2009) bahwa pemberian masalah akan merangsang pemikiran siswa untuk membuktikannya. Dengan demikian, siswa terdorong untuk mencari pemecahan masalah dengan cara menentukan rumusan masalah yang akan dipecahkan, mencari teori-teori yang mendukung untuk solusi pemecahan masalah, menguji sendiri kebenaran teori yang telah dipilih sebagai solusi pemecahan masalah, serta menyimpulkan hasil 


\section{Chemistry Education Practice,2 (2), 2019 - 23}

Hasinah Martini

pembelajaran dalam bentuk konsep baru sebagai jawaban pemecahan masalah. Demikian pula, hasil penelitian Indrayanti (2006) yang menyatakan bahwa metode pembelajaran problem solving efektif meningkatkan kreatifitas siswa sehingga dapat meningkatkan prestasi belajar siswa.

Berdasarkan pemikiran di atas, peneliti tertarik untuk mengetahui efektivitas penggunaan metode pembelajaran problem solving dalam meningkatkan hasil belajar siswa kelas X IPA 1 SMAN 2 Mataram pada materi konsep mol, dan menuangkan dalam suatu laporan penelitian tindakan kelas (Laporan PTK) dengan judul "Penerapan metode pembelajaran problem solving untuk meningkatkan hasil belajar siswa pada materi konsep mol di kelas X IPA 1 SMAN 2 Mataram Semester 2 Tahun Pelajaran 2016/2017".

\section{METODOLOGI PENELITIAN}

Pada penelitian ini, digunakan metode Penelitian Tindakan kelas (Classroom Action Research). Metode PTK ini digunakan karena metode ini memiliki peranan yang sangat penting dan strategis untuk meningkatkan mutu pembelajaran apabila diimplementasikan dengan baik dan benar. Diimplementasikan dengan benar artinya pihak terlibat dalam PTK yang dalam hal ini adalah guru mencoba dengan sadar mengembangkan kemampuan dalam mendeteksi dan memecahkan masalah-masalah yang terjadi dalam pembelajaran di kelas melalui tindakan bermakna yang diperhitungkan dapat memecahkan masalah atau memperbaiki situasi dan kemudian secara cermat mengamati pelaksanaannya untuk mengukur tingkat keberhasilannya. Diimplementasikan dengan benar artinya sesuai dengan kaidah-kaidah PTK.

Pada penelitian tindakan kelas ini, peneliti memfokuskan penelitian pada upaya peningkatan hasil belajar siswa kelas X MIPA 1 SMAN 2 Mataram dengan menggunakan metode pembelajaran problem solving. Tujuannya adalah untuk mengetahui efektifitas atau kemanjuran metode pembelajaran problem solving dalam upaya meningkatkan hasil belajar siswa, serta mengetahui seberapa besar peningkatan hasil belajar siswa dengan menggunakan penggunaan metode pembelajaran problem solving pada materi konsep mol.

Penelitian tindakan kelas ini dilaksanakan di SMAN 2 Mataram pada semester 2 tahun pelajaran 2016-2017 yaitu dari tanggal 9 Januari s/d 13 Pebruari 2017 sesuai dengan kalender pendidikan atau kalender akademik sekolah serta Rencana Program Pembelajaran (RPP) yang telah guru/peneliti buat.

Dalam penelitian tindakan kelas ini, analisis data yang dilakukan adalah analisis data kuantitatif dan analisis kualitatif. Analisis data kuantitatif yaitu nilai hasil belajar siswa berupa post test tiap akhir siklus. Hasil belajar diberikan skor untuk masing-masing soal. Skor-skor tersebut kemudian dikonversi ke dalam nilai akhir. Nilai-nilai tersebut kemudian disajikan dalam bentuk tabel distribusi frekuensi untuk selanjutnya dilakukan perhitungan mencari nilai rata-rata dan standar deviasi. Setelah didapatkan nilai rata-rata post test tiap siklus, dilakukan pengujian dua sampel yang bertujuan untuk mengetahui perbedaan peningkatan hasil belajar siswa antara siklus I dengan siklus II.

Adapun data kualitatif yaitu data yang berupa informasi berbentuk kalimat seperti data hasil observasi yang memberi gambaran tentang sikap guru dan siswa terhadap pembelajaran kimia dengan menerapkan metode problem solving. Data yang berisi partisipasi keaktifan siswa dianalisis langsung menggunakan lembar observasi di setiap siklus dengan skala $<50 \%$, $50 \%$, dan $>50 \%$. Data kemudian diinterprestasikan secara deskriptif sesuai dengan data yang ada pada lembar observasi. Sedangkan data yang bersumber dari angket yang menunjukkan sikap siswa terhadap pembelajaran dengan menggunakan metode problem solving diperoleh dengan mencari persentase dari setiap pertanyaan pada lembar angket kemudian diinterprestasikan dengan menggunakan grafik yang akan menunjukkan apakah terjadi peningkatan atau penurunan persentase pada sikap siswa. Rumus yang digunakan untuk menghitung persentase sikap siswa yaitu :

$$
\begin{aligned}
& \mathrm{P}=\mathrm{f} / \mathrm{N} \times 100 \% \\
& \text { Keterangan: } \\
& \mathrm{F}=\text { frekuensi } \\
& \mathrm{N}=\text { jumlah siswa } \\
& \mathrm{P}=\text { angka presentase }
\end{aligned}
$$

Pada model ini tahapan penelitian dibagi menjadi empat tahap: (1) perencanaan, (2) pelaksanaan, (3) pengamatan, dan (4) refleksi, kemudian dilanjutkan ke siklus berikutnya.

Adapun tahapan penelitian ini dapat digambarkan sebagai berikut: 
Hubungan keempat komponen itu dipandang sebagai satu siklus. Secara visual hubungan keempat komponen dalam sistem siklus dapat di gambarkan sebagai berikut :

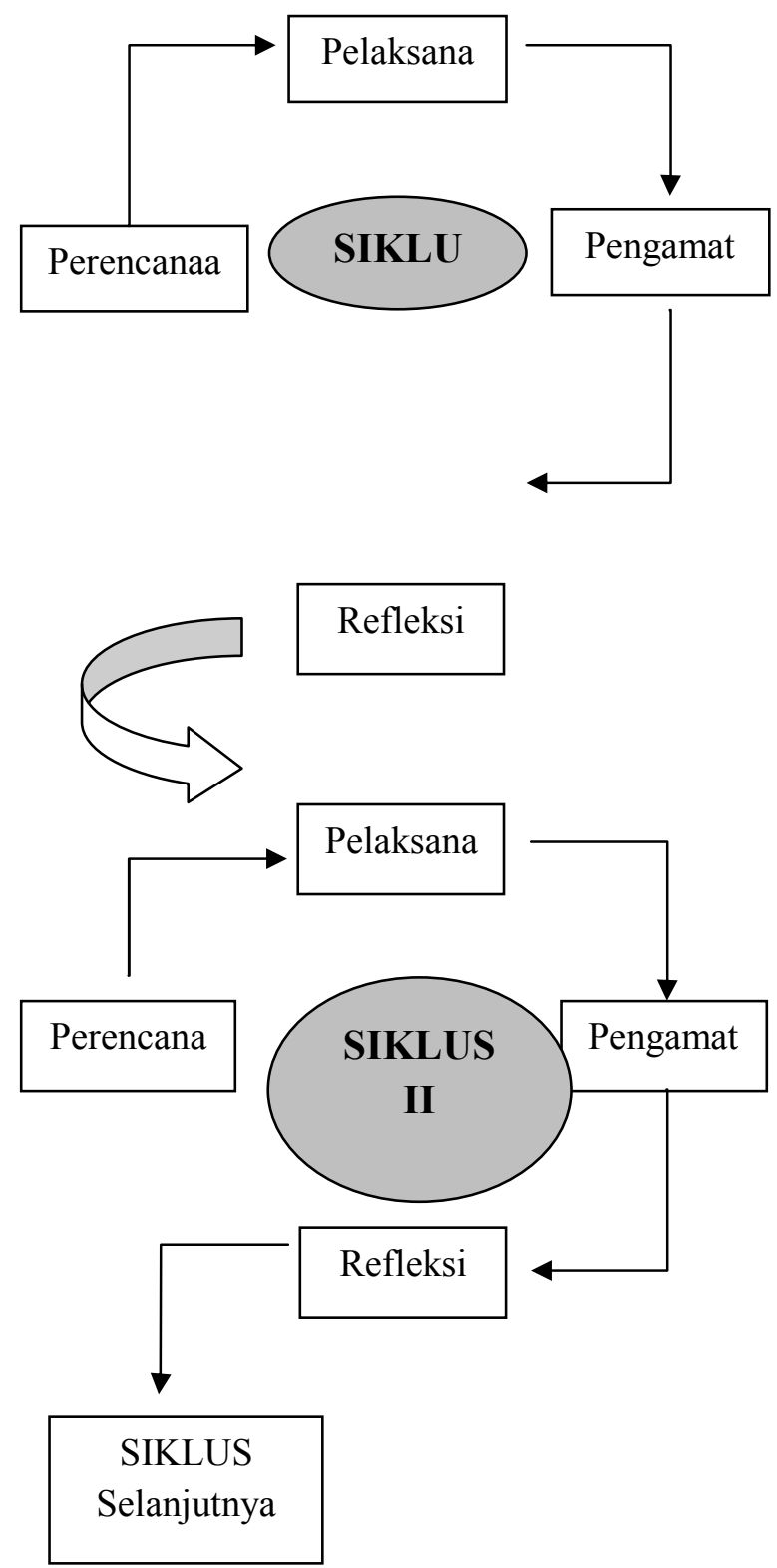

Gambar 1. PTK Model John Elliot

Kegiatan penelitian tindakan kelas ini dirancang dan akan dilaksanakan dalam 2 (dua) siklus, yaitu siklus I dan siklus II. Pada siklus I dan siklus II terdiri atas perencanaan, pelaksanaan, pengamatan, dan refleksi. Pelaksanaan tiap siklus akan diambil satu kelas yang sama. Hal ini ditempuh untuk membandingkan dan menggambarkan proses pembelajaran pada tiap-tiap siklus. Sebagai langkah-langkah besar yang akan dilakukan adalah sebagai berikut:

\section{Siklus I}

a. Perencanaan

Pada kegiatan ini guru melakukan :

1) Merencanakan pembelajaran dengan membuat Rencana Pelaksanaan Pembelajaran (RRP) dengan menggunakan metode pembelajaran problem solving.

2) Menyiapkan LKS (Lembar Kerja Siswa) yang digunakan sebagai bahan diskusi siswa.

3) Menyiapkan instrumen penelitian (lembar observasi, tes evaluasi dan angket siswa/i)

b. Pelaksanaan

Pada kegiatan ini guru:

1) Melaksanakan kegiatan pembelajaran sesuai dengan RPP yang telah dibuat.

2) Melaksanakan tahapan-tahapan dalam pembelajaran menggunakan metode pembelajaran problem solving.

c. Pengamatan

Pada kegiatan ini, kolaborator (observer) melakukan pengamatan dengan mencatat :

1) Aktivitas dan gaya guru dalam melaksanakan pembelajaran dengan menggunakan model pembelajaran problem solving

2) Aktivitas siswa selama proses pembelajaran berlangsungdengan menggunakan model pembelajaran problem solving dan melakukan wawancara setelah pembelajaran selesai.

d. Refleksi

Pada kegiatan ini :

1) Guru dengan observer membahas tentang kelemahan atau kekurangan proses pembelajaran yang telah dilakukan 


\section{Chemistry Education Practice,2 (2), 2019 - 25}

Hasinah Martini

2) Menganalisis data yang diperoleh untuk memperbaiki dan menyempurnakan tindakan pada siklus selanjutnya

3) Menganalisis temuan saat melakukan pengamatan proses pembelajaran yang telah dilakukan menganalisis kelemahan dan kelebihan dari proses pembelajaran yang berlagsung mempertimbangkan langkah selanjutnya.

\section{Siklus II}

Pada siklus II, peneliti berdiskusi dengan observer melakukan revisi proses pembelajaran, agar proses pembelajaran pada siklus II menjadi lebih baik. Siklus II ini dilaksanakan dengan mengikuti tahapan-tahapan seperti pada siklus I. Tapi, pada siklus II ini dilakukan perbaikan atau penyempurnaan terhadap pelaksanaan pembelajaran siklus I agar mencapai indikator keberhasilan yang telah ditetapkan.

Dalam penelitian tindakan kelas ini, pengumpulan data dilakukan dengan menggunakan teknik :

1) Pengamatan (observasi)

Observasi merupakan kegiatan pengamatan (pengambilan data) untuk mengamati aktivitas siswa dan guru selama proses pembelajaran. Observasi ini menggunakan lembar observasi sistematis di mana observer menggunakan pedoman observasi sebagi instrumen pengamatan. Observasi ini juga digunakan untuk mengungkapkan sejauh mana metode pembelajaran Problem Solving dapat diterapkan.
Sedangkan lembar observasi untuk mengamati aktivitas guru dapat dilihat pada tabel berikut,

2) Tes

Teknik tes digunakan untuk mengumpulkan data dan gambaran tentang kemampuan siswa memahami pelajaran selama proses pembelajaran, mengukur hasil belajar siswa, dan mengetahui kemampuan siswa memecahkan masalah terhadap soal-soal konsep mol. Tes berupa soal uraian yang tiap soalnya mencakup jenjang C2. C3, C4 dan C5. Dari jawaban siswa dapat diperoleh seberapa besar tingkat pemahaman siswa terhadap materi yang telah diajarkan. Begitu pula dengan kemampuan pemecahan masalah terhadap soal tersebut.

3) Wawancara

Angket digunakan untuk mengukur sikap siswa dan memperoleh gambaran data dari setiap siswa terhadap pembelajaran dengan menggunakan pendekatan Problem Solving. Angket yang digunakan adalah angket pertanyaan yang memiliki pilihan jawaban yang sesuai dengan yang dirasakan siswa.

\section{HASIL DAN PEMBAHASAN}

Setelah dilakukan tindakan pembelajaran dengan menggunakan metode problem solving pada siklus II diperoleh hasil sebagai berikut:

1) Ketercapaian ketuntasan belajar siswa dari siklus I ke siklus II telah terjadi peningkatan pada siklus II.

2) Siswa sudah mampu menyelesaikan soal dengan metode problem solving.

3) Siswa merasa senang selama proses pembelajaran dengan metode problem solving karena mereka dapat meningkatkan kemampuan mereka dengan latihan-latihan yang diberikan.

4) Pada siklus II diperoleh ketuntasan dan aktivitas belajar siswa yang meningkat dan telah mencapai indikator keberhasilan yang telah ditetapakan. Oleh karenan itu peneliti memutuskan untuk menghentikan penelitian pada siklus II ini.

Berdasarkan hasil penelitian yang dilakukan di kelas X IPA 1 pada materi konsep mol dengan 


\section{Chemistry Education Practice,2 (2), 2019 - 26 \\ Hasinah Martini}

menggunakan metode pembelajaran problem solving, selama pembelajaran berlangsung secara keseluruhan dari siklus I ke siklus II diperoleh data sebagai berikut:

1) Hasil belajar siswa

Berdasarkan hasil belajar siswa dari pada siklus I dan siklus II diperoleh data seperti pada tabel 1 berikut.

Tabel 1. Hasil belajar siswa pada siklus I dan II Siklus Rata-rata Persentase

\begin{tabular}{ccc} 
& nilai & \\
\hline I & 65,67 & 40 \\
II & 79,08 & 88
\end{tabular}

2) Tingkat pemahaman pemecahan masalah siswa

Dari hasil pembelajaran pada siklus I dan siklus II terjadi peningkatan pemahaman siswa dalam menerapkan tahap-tahap pemecahan masalah seperti pada grafik 4.1 berikut.

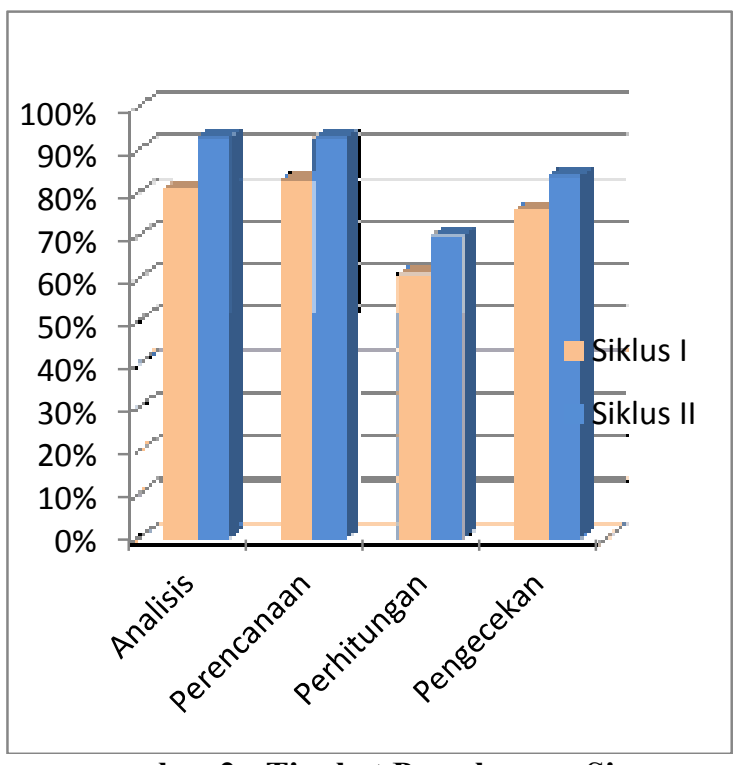

gambar 2 : Tingkat Pemahaman Siswa

3) Sikap siswa

a) Sikap siswa terhadap proses pembelajaran

Peningkatan sikap siswa terhadap proses pembelajaran yang mereka ikuti dari siklus I ke siklus II dapat di visualisasikan dalam bentuk grafik 2 berikut.

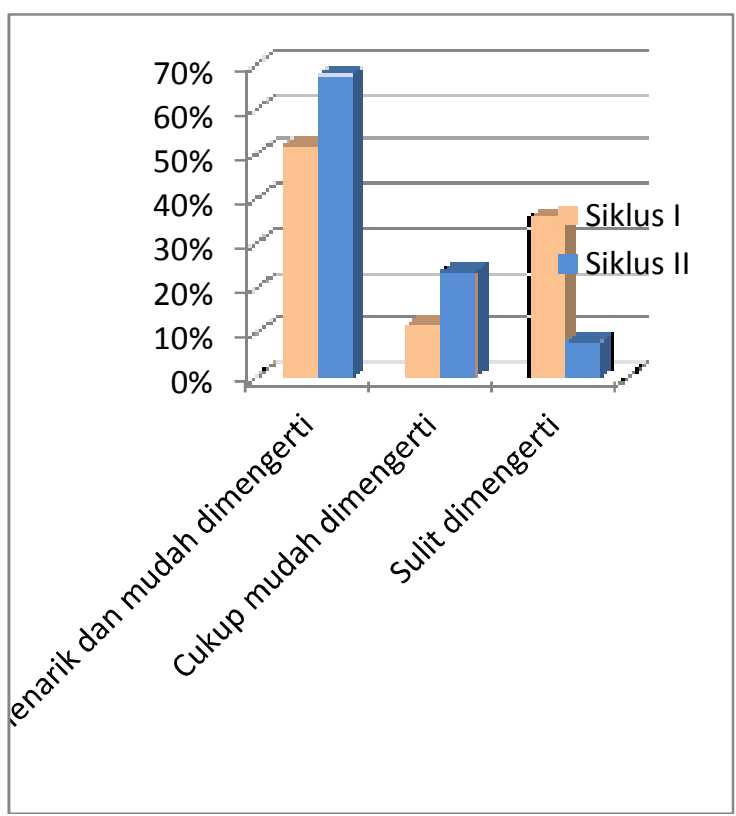

Gambar 3. Sikap siswa terhadap proses pembelajaran

b) Sikap siswa terhadap materi pelajaran

Peningkatan sikap siswa terhadap materi pelajaran dari siklus I ke siklus II dapat di visualisasikan dalam bentuk grafik 3 berikut.

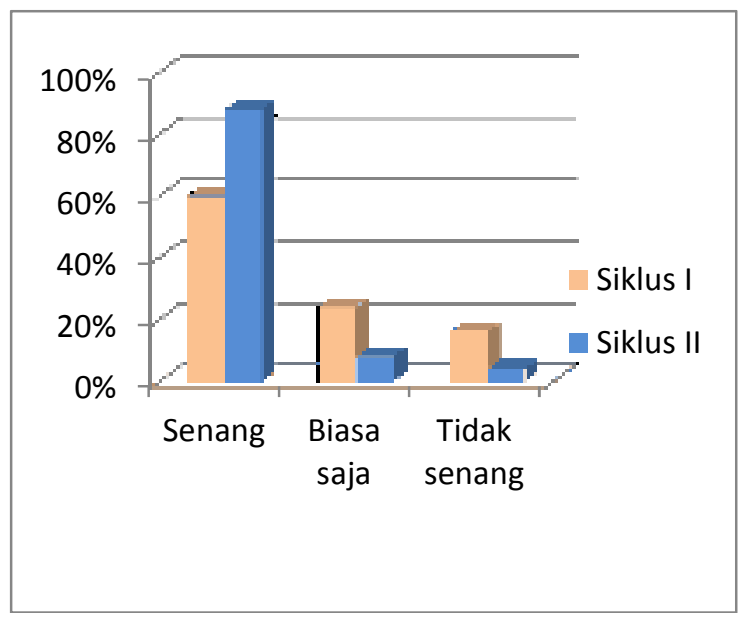

Gambar 4. Sikap siswa terhadap minat pada materi pelajaran

c) Sikap siswa terhadap cara guru menyampaikan materi pelajaran

Peningkatan sikap siswa terhadap cara guru menyampaikan materi pelajaran dari siklus I ke siklus II dapat di visualisasikan dalam bentuk gambar 5 berikut. 


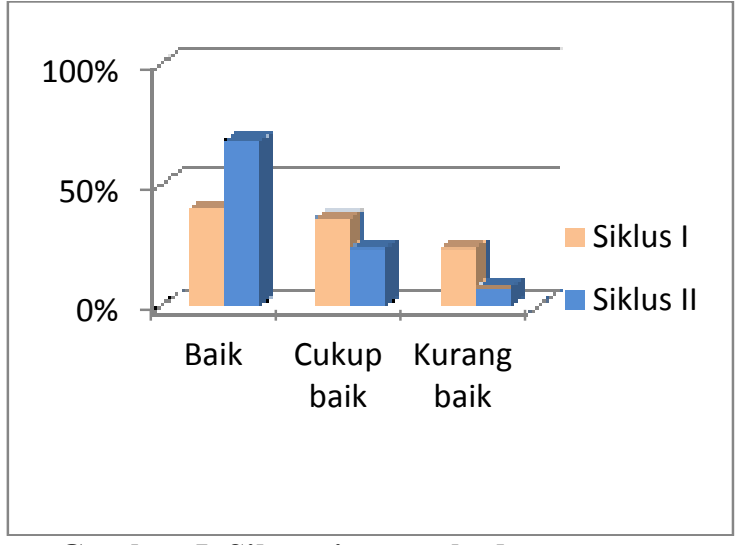

Gambar 5. Sikap siswa terhadap cara guru menyampaikan pelajaran

d) Sikap terhadap pemahaman materi yang dipelajari

Peningkatan sikap siswa terhadap pemahaman materi yang dipelajari dari siklus I ke siklus II dapat di visualisasikan dalam bentuk grafik 5 berikut.

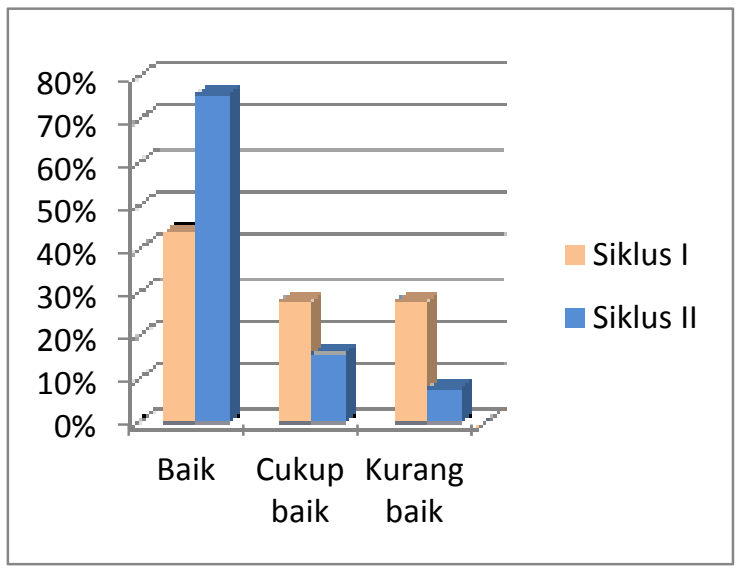

Gambar 6. Sikap siswa terhadap cara guru menyampaikan pelajaran

e) Sikap siswa terhadap evaluasi yang diberikan guru

Peningkatan sikap siswa terhadap evaluasi yang diberikan guru dari siklus I ke siklus II dapat di visualisasikan dalam bentuk grafik 6 berikut.

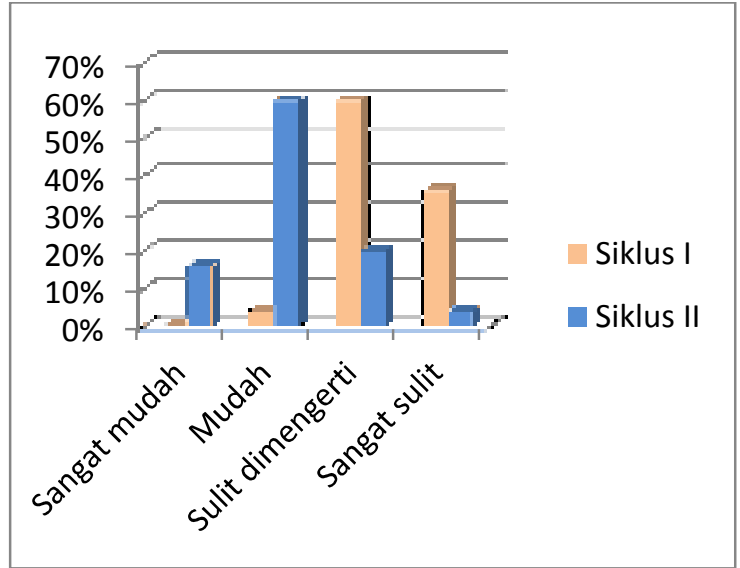

Gambar 7 : Sikap siswa terhadap cara guru menyampaikan pelajaran

\section{KESIMPULAN}

Berdasarkan hasil penelitian dan pembahasan yang telah diuraikan sebelumnya, dapat diambil kesimpulan bahwa setelah dilakukan kegiatan pembelajaran dengan menggunakan pendekatan problem solving dengan 4 (empat) tahapan yaitu analisis dimana siswa terlebih dahulu memahami masalah dengan mengumpulkan data yang diperoleh dan menentukan inti permasalahan yang harus dipecahkan. Selanjutnya membuat sebuah perencanaan dengan menentukan langkahlangkah ataupun rumus-rumus yang akan digunakan untuk menyelesaikan permaslahan tersebut, selanjutnya melakukan perhitungan sesuai dengan langkah-langkah ataupun rumusrumus yang digunakan, dan terakhir melakukan pengecekan untuk mengetahui ketepatan jawaban yang diperoleh. Hasil belajar kimia siswa pada materi konsep mol dari siklus I ke siklus II mengalami peningkatan.

Dari proses pembelajaran pada siklus I dan II didapatkan nilai rata-rata hasil belajar pada post test I adalah 65,67 dan persentase siswa yang mencapai nilai $\geq 76$ adalah $40 \%$. Setelah dilakukan perbaikan-perbaikan pada tahap-tahap penyelesaian masalah, ringkasan materi yang diberikan kepada siswa, cara penyampaian materi oleh guru, metode pembelajaran yang dilakukan pada siklus II, rata-rata hasil post test siswa mencapai 79,08 dan persentase siswa yang mendapatkan nilai $\geq 76$ adalah $88 \%$. Angka ini sudah cukup bahkan melebihi dari batas ketercapaian yang ditentukan. Artinya bahwa penelitian ini dapat dikatakan berhasil. 


\section{Chemistry Education Practice,2 (2), 2019 - 28}

Hasinah Martini

\section{DAFTAR PUSTAKA}

Arsyad, A. 2002.Media Pembelajaran. Jakarta: Rajawali Press.

Astuti, Y \& Setiawan,B. 2013.Pengembangan Lembar Kerja Siswa (LKS) Berbasis Pendekatan Inkuiri Terbimbing dalam Pembelajaran Kooperatif pada Materi Kalor.Jurnal Pendidikan IPA Indonesia.3 (1).

Himawan., Yunus, M \& Sugiarti. 2017. Pengaruh Model Pembelajaran Team Assisted Individualizationterhadap Hasil Belajar Siswa Kelas X SMA Negeri 2 Polewali (Materi Pokok Ikatan Kimia). Jurnal Chemica. 18(1).92-100.

Munandar, W. A. 2016. Media Mind Map Untuk Meningkatkan Retensi Siswa Dalam PembelajaranPendidikan

Kewarganegaraan Kelas III. Jurnal Pendidikan Guru Sekolah Dasar.5(18).234-244.

Nurazizah, S. 2015. Pengaruh Pembelajaran Team Assisted IndividualizationBerbantuan Study Card Terhadap Hasil Belajar Materi HidrolisisSiswa Kelas XI SMA Negeri 1 Candiroto Temanggung. Skripsi FMIPA Universitas Negeri Semarang.

Sanjaya, W. 2008.Strategi Pembelajaran Berorientasi Standar Proses Pendidikan. Jakarta: Kencana Prenada Media Group.

Sugiyono. 2012. Metode Penelitian Kuantitatif, Kuantitatif dan $\mathrm{R}$ \&D . Bandung: Alfabeta.

2014. Metode Penelitian Kuantitatif, Kuantitatif dan $\mathrm{R} \& \mathrm{D}$. Bandung: Alfabeta.

Suyanti, R. D. 2010. Strategi Pembelajaran Kimia. Yogyakarta: Graha Ilmu.

Suyanto.2010. Strategi Pembelajaran Kimia. Jakarta: Yudistira.

Utami, D. D, Hastuti, Budi Dan Redjeki, Tri. 2015. Upaya Peningkatan Aktivitas dan Prestasi Belajar Siswa Kelas XI IPA 2 dengan Menggunakan Model

Pembelajaran Kooperatif Tipe Team

Assisted Individualization (TAI)

Berbantuan Demonstrasi Pada Materi Hidrolisis GaramDi SMA Negeri 1 Banyudono Boyolali Tahun Pelajaran 2013/2014. Jurnal Pendidikan Kimia (Jpk). 4(1).157-164. 